\title{
РАЗУМ, РАЦИОНАЛЬНОСТЬ, СУБЪЕКТ
}

\section{А.И. Абдула}

Современная философия формирует во многом специфическое, относительно предшествующих эпох, представление о познавательной деятельности человека. С одной стороны, оно проявляется как форма выражения и развития той ключевой тенденции, утвердившейся в Новое время и нашедшей свое более позднее отражение в прагматизме, аналитической философии и других влиятельных направлениях современности, в соответствии с которой, научное познание и практика обнаруживаются не только как способы раскрытия истины, но и как средства конструирования самой реальности. В этом смысле показательным является высказывание основателя прагматизма Ч. Пирса о том, что «обучение у Канта» проходили «девятнадцать из каждых двадцати обратившихся к философии экспериментаторов» [17, с. 149].

С другой стороны, в современных экзистенциально-феноменологических и иных модификациях «коперниканского переворота» обнаруживается проблематичность выявления и обоснования той степени определенности, которую содержат в себе конституирующие реальность познавательные формы. Субъективность в этой перспективе утрачивает свой рациональный фундамент, она конституируется посредством апелляции к иррациональному, вписывается в реальность как одно из его проявлений. Возникает соответствующая интерпретация проблемы оснований, которая предполагает, по выражению Л. Витгенштейна, что «на дне обоснованной веры лежит необоснованная веpa» $[7$, c. 353].

В этом взгляде на перспективу самоопределения человека, оценку его возможностей приблизиться к истине, а, следовательно, и к объективной реальности отражается, на наш взгляд, одна из ключевых 
особенностей эпохи постмодерна. Но подобная характеристика предполагает и другую оценку - понимание того, что субъективность практически всегда отвергает внутреннюю замкнутость - она есть выход за собственные пределы, не только в сторону реконструкции «объективного» мира и «чистого» знания, но в сторону другого субъекта «чтобы ошибаться, человек уже должен судить согласно с человечеством» $[7$, с. 343]. Пониманию того, что эта взаимосвязь становится определяющей мерой бытия, соответствует, на наш взгляд, тот уровень рефлексии, который можно уловить в современном философском дискурсе.

Утвердившийся в плюралистической субстанциальности субъект, в воссозданном им же самим мире вновь вынужден ставить вопрос о пределе его внутренней и внешней определенности, фиксируемом уже не в чистых, априорных познавательных или практических формах, но как едва различимая граничность. Объективность же, формирующаяся с учетом и на основе этой неустойчивой субъективности, хотя и понимается как анти-релятивность, исходность, относительная независимость, но обнаруживается посредством сомнения и проявляется как неустойчивость, поскольку интенции к совпадению в объективности реальности и знания скрепляет «снизу» сам субъект.

Это совпадение перенаправляет познавательный интерес в сторону субъектной интерпретации системы основополагающих, формирующих, создающих реальность идей, которые в определенном смысле тождественны самой реальности и могут быть выражены с помощью категории «разум». Особое значение в такой системе познавательных координат приобретает прояснение статуса существующего «вне» этих идей (вне разума) «нечто» (см., напр.: [22]).

Вместе с тем, в ходе современного дискурса не теряют актуальности и ряд традиционных вопросов, относящихся к проблематике разума. Из их числа следует выделить, прежде всего, классическую проблему экспликации форм (категорий) проявления разума, перспективу дополнения их чем-то принципиально новым в противовес их внутренней и внешней самодостаточности (см., напр.: Платон [19]). Показательно, что выявление качественных аспектов внутреннего прогресса, в соответствии с более поздними, по отношению к Античности, представлениями, потребовало аргументированного обращения к историко-философскому анализу. Здесь находит выражение позиция (наиболее ярко выраженная в учении Гегеля [8], что направления философии (ее разделы) исторически отображают качественные уровни разработки категорий, их границы и структуру. И если для близкого к 
подобному пониманию религиозного мировоззрения категории («Бытие», «Истина», «Прекрасное», «Добро» и т д.) могут сливаться в понятии «Бог», то в иных ценностно-познавательных координатах они способны «пересекаться» и даже противопоставляться друг другу, выглядеть «смутными» и неразличимыми, в зависимости от эпохи, цивилизации, народа. Последнюю точку зрения можно проиллюстрировать следующим высказыванием Г. Лебона:

В действительности, как бы ни был развит и одарен какой-нибудь народ, его способность усваивать тот или другой новый элемент цивилизации всегда очень ограничена [13, с. 76-77].

Соответственно, требует прояснения и еще одна важная проблема - соотношения внутренних и внешних границ различных форм разума (см.: [21]). Так, например, можно задаться вопросом, существует ли «эстетический разум» и находит ли «эстетическое» осмысленность в некотором контексте вне эстетики. Казалось бы, нечто выходящее за внешние пределы разума приобретает (что легко обнаруживается в социальной среде) негативную окраску, тем более, чем сильнее идея развита, структурирована, разработана. Однако, если идея «тусклая», едва заметная, то ее границы неясны и расплывчаты. Идея может быть и «яркой», но в то же время, неопределенной, неразвитой, неструктурированной внутри (например, абсолютный запрет на то или иное действие - табу).

В этой связи возникает необходимость разрешения также и проблемы прогресса разума, завершения его внутренней борьбы, прояснения результатов и целей его упорядочивающей деятельности. В рационально-оптимистической интерпретации таким результатом является абсолютная определенность - «бытия», «истины», «красоты», «добра» в их взаимосвязи. Однако, если допустить подобную завершенность, исчезает ли «внешняя» неопределенность? Отметим, что такая постановка вопроса и поиск ответа на него задействуют в качестве одного из основных понятий проблематики разума еще одну категорию - категорию «свободы». Если в исходной точке развития можно говорить о «свободе» как об изначальном «произволе», при котором все идеи расплывчаты и не сформированы, о свободе внутри хаоса, то в конечной перспективе - о свободе внутри порядка, как об абсолютном разуме, когда все идеи «завершены». В этом состоянии «внутри» категорий «пустых мест» нет. Обнаруживаются ли они «вне»?

Возвращаясь к началу, существует ли вообще эта внешняя, по отношению к разуму, неопределенность? Если следовать Гегелю, то такого 
внешнего, абстрактного, обособленного (метафизического) неразумия не существует и развертывание разума происходит «внутри» круга категорий, то есть внутри диалектически слитого «бытия» и «небытия» [8]. Однако, современный рационализм далеко не так оптимистичен, не только потому, что он агностичен и иррелигиозен, но и поскольку вынужден зафиксировать реальность иррационального.

На этом фоне вновь актуализируется вопрос природы разума и того, что стоит за ним. Это и есть вопрос «критики разума», но не в том смысле, как именно он осуществляет познавательные операции, а в значении его пределов или границ, тематики взаимоперехода разума и неразумия, порядка и хаоса, бытия и небытия. Можно сказать, что, в определенном смысле, это вопрос философского оптимизма и пессимизма. Однако, во-первых, имеет место материал для исследования, почва для него, и это не спонтанные, ситуативные предпочтения, а история в максимально широком смысле - история науки, религии, искусства, и даже практики и обыденности. И во-вторых, это не один аспект проблемы, как-то «гносеологический» или «этический» оптимизм либо пессимизм. Это вопрос совокупности различных форм разума, их развертывания и уточнения на протяжении различных эпох. Даже если оставить вопрос реальности внешнего хаоса без ответа, то сама эта безответность в определенном смысле является ответом (таким, какой, например, дал Кант), и, вместе с тем, по силе внутреннего хаоса (тех пробелов, неуточненностей внутри развертывания понятий) можно составить представление о тенденции в соотношении разума и неразумия.

Выделив ряд вопросов, связанных с пониманием разума (взаимосвязи между его категориями, их развития и оппозиционности), далее мы рассмотрим возможные пути их прояснения, исходя из представляющейся нам фундаментальной концепции субъективности. Способ постановки вопросов и их детализация подсказывают нам методологические основания, допустимые при исследовании такого рода: обращение к истории философии и к истории как к материалу исследования, анализ понятий в их развитии и противопоставлении, выделение целостной системы и ее структур. Дальнейшее содержание определяется этими предпосылками.

Прежде всего, следует подчеркнуть, что исследование разума, стремление к познанию его сущности, постижение его основных форм как основы субъективного и объективного, формируют одну из ключевых тем духовного освоения мира, являются определяющим направлением на пути самопознания человечества. Движущая сила в этом исследо- 
вании принадлежит философии, как высшей форме теоретической рефлексии, воплощенному разуму, который пытается найти себя, прежде всего, в себе самом, а затем, насколько это вообще возможно, выйти за собственные пределы. Философский поиск никогда не видится застывшим, а его результат окончательным, поскольку постоянно изменяется предмет его исследования, изменяется и он сам. В этом предмете, как области распространения разума, отражается не только философия, но и религия, мораль, наука, общество.

Изменчивость разума проявляется в виде его постоянной внутренней борьбы, переходов к новым состояниям, усложнения структуры. Эти переходы в своей общей тенденции понимаются как прогресс или даже экспансия: настолько всеохватывающей становится рационализация. Вместе с тем, разуму, казалось бы, противостоит всякий раз нечто большее, чем его внутренняя, содержательная неопределенность или отжившие свое его ранние формы, то, что стоит за этой неопределенностью: ее источник, исходная пустота или даже чуждая разуму активность. Это особое, находящееся за пределами разума состояние, «безумие» (по поводу экспликации этой категории см., напр., работу М.Фуко: [26]), может рассматриваться, не только в виде его искажения, отрицания (на которое указывает структура и происхождение термина), своего рода иллюзии, но и в качестве особой сущности, претендующей на самостоятельное бытие. Подобное восприятие разума предполагает, что в отношении своей противоположности он не воспринимается как нечто абсолютное, устойчивое и универсальное, а скорее представляется тем, что следует искать или, по крайней мере, оправдывать в его изменчивых проявлениях. Поскольку разум обнаруживается в различных формах, такое оправдание неизбежно вплетается в систему оппозиций: добро-зло, порядок-хаос, истина-заблуждение.

Идея разума, как идея его поиска и оправдания, может восприниматься в качестве идеи пессимистической (даже если рассматривать ее как определенную форму методологии исследования), в той мере, в какой она предполагает не столько наличие самого «безумия» или «неразумия», сколько первичность последнего по отношению к разуму, исходный хаос, который не под силу преодолеть разумному порядку. Разум наделяется позитивным (моральным, познавательным) содержанием, и, вместе с тем, констатируется его слабость, поскольку ставится под сомнение наличествующая либо потенциальная разумность бытия в целом или в его отдельных проявлениях. Он не может быть чем-то исходным, поскольку оказывается «всего лишь» переходящим, 
неполноценным «не-безумием», игрой сил хаоса. В противном случае, пессимистическая установка предполагает, что существующее разумное основание постоянно деградирует, что делает его поверхностным и временным, вновь возвращая к идее всесильности неразумия.

Существует искушение выйти за пределы такого пессимизма, лишив разум позитивного содержания. В этом случае он будет восприниматься в качестве одной из внешних сил (по аналогии с силами природы), видимой лишь как «граница», которая легко сливается со своей противоположностью, мало отличается от того, что может находиться «по ту сторону», где обнаруживают волю к жизни и к власти (Шопенгауэр [27], Ницше [16]), стремление к любви и разрушению (Фрейд [24]) и т. п., взятые сами по себе, как «естественные» и «слепые» силы. Сужение сферы поиска разума до бытия человека позволяет обнаружить ограничивающие и упорядочивающие функции разума, которые хотя и сохраняют свое значение, но становятся «расплывчатыми» и «прозрачными», готовыми, как их источник, «раствориться» во внешних проявлениях природы или общества.

Перспектива отрицательного результата в поиске разума, констатация его бессилия либо исчезновения, в большей степени соответствует мировоззрению современной эпохи. Однако проблематика разума раскрывается и как противоположная традиция, которая находит почву для оптимизма. Древнегреческая мифология, повествующая об упорядочивании мира разумным началом и противопоставляющая этому началу первозданный хаос, во многом определила мировоззрение античности, в соответствии с которым природа олицетворяет гармонию и порядок. Отрицание этого порядка понимается как иллюзорное искажение (несовершенным чувственным восприятием) исходного состояния, высшей нормы, как правило наделяемой позитивной субстанциальностью и моральным содержанием (Платон [18]).

Разрыв между божественным и земным мирами в христианском мировоззрении отделяет, вслед за платониками, сферу борьбы от сферы божественного порядка, которая символизирует собой высший порядок бытия. Божественный разум уже не столько очищает пораженное неразумием бытие, сколько оставляет место для иллюзии хаоса (зла) там, где ощущается недостаток порядка (добра) (см.: Августин [2]). Так, согласно Августину, абсурдной представляется точка зрения, согласно которой: «благой Бог [...] смешал со злом Свою добрую природу $[. .$.$] с большим трудом едва очищает и освобождает, хотя и не$ все» [3, с. 492]. Тогда как: «природа Божия, какова она есть, неизменяема и совершенно нетленна, и потому ей ничто не может вредить» 
[там же]. Что же до разума человеческого, то, по мнению Августина:

Каждому, кто способен так или иначе пользоваться разумом, ясно, что все люди желают быть блаженными. [...] Но человеческая душа, хотя она безусловно и разумна, - не может быть блаженной иначе, как только вследствие общения со светом [...] Бога [там же, с. 403].

Разум, упорядочивающий, очищающий, но уже как разум субъективный, вновь обретает свое значение в качестве основного мотива рационализма Нового времени. С одной стороны, допускается возможность его ограниченной причастности к божественной субстанции. Трансцендентальность ratio в виде «врожденных идей» Декарта [10] и «априорных форм» Канта [12] рассматриваются как проявления божественной воли, познать которую человек полностью не в состоянии. С другой стороны, это обособленность индивидуального, субъективного разума, его автономность, возвращает оптимизм на почву земного, человеческого, социального, перенося его в сферу позитивного знания.

За пределами этой сферы божественный разум для «конечного» человеческого ума все еще может проявляться в виде непостижимой внешней силы. Однако вопрос о ее характере в конструируемом наукой мире постепенно теряет свое первостепенное значение, пока, наконец, благодаря позитивизму, не приобретает статус псевдопроблемы. В иной традиции, предполагающей единство этой силы с бытием, тождественность мышления и бытия (Гегель [8]), попытка демистификации приводит к обезличиванию, трансформации разума во «внешние», «объективные» законы, направляющие природу и общество (Маркс [14]).

Исчезновение божественного разума, его «смерть», которую констатировал Ницше, потребовала укрепления позиций «земного» разума, прежде всего, как разума позитивного (научного), поскольку природа последнего на протяжении практически всего пути его развития подразумевала апелляции к высшим принципам, которые благодаря его же собственной деятельности оказались несостоятельными. Наука обнаружила себя запертой в собственном лишенном фундамента мире (см.: Э.Гуссерль [9]). Само по себе это уже могло означать отказ от всеохватывающей оптимистической установки в познании и практике. Осознавший свою ограниченность разум, этот новый рационализм в версиях Ч. Пирса или К. Поппера (см.: [17], [28]), вынужден был довольствоваться малыми, «частными» успехами, находясь в плену противоречий постоянно фиксировать собственную, пусть и потенциальную, «ошибочность». Ошибки призваны были стать связующим звеном между знанием и реальностью. Лишь игнорируя их, 
человек, это «несовершенное логическое животное», «находится в состоянии благодушия и самоуспокоенности», однако результаты опыта «постоянно разрушают его надежды и устремления» [17, с. 97]. Разум, как средство приспособления к реальности, теперь противостоял самой этой реальности, как исходному материалу, который необходимо обработать, огранить, но который постоянно исчезал, растворялся, терял целостность и менял форму. Эта изменчивость и неустойчивость проникала и в сам разум, который не мог быть чем-то принципиально отличным от того, что ему противостояло, поскольку понимался как инструмент познавательной, а, следовательно, и социальной эволюции. Его конкретные проявления и его рефлексия стали ситуативноисторическими за исключением самой ошибочности, которая обеспечивала его развитие (см.: [28]).

Преодоление панрационалистической метафизики требовало исключить вопрос об объективном источнике порядка (его сущности) и в качестве его замещения использовать представление об объективных законах природы и, возможно, закономерностях истории. Это привело к тому, что в качестве одной из основных областей исследования, помимо философии и науки, закрепляется сфера социального, в которой, как предполагалось, особой, упорядочивающей и контролирующей силой, выступает сам субъект (в той мере, в какой социальный порядок связывается с его деятельностью). Такое перенаправление познавательных запросов, соответствовавшее духу позитивной методологии, дало возможность выявлять социальные процессы и структуры через их конкретные, непосредственно воспринимаемые формы (Э. Дюркгейм [11], М. Вебер [6] и др.).

Предпринятый социальными науками анализ типов рациональности, психологические исследования в этом направлении лишь закрепили представление о ключевой роли иррациональных или неподвластных рационализации сил в социальной жизнедеятельности. «Неразумие» обнаруживалось как слабо поддающаяся рациональной обработке среда: масса, составляющая основу современного общества, самоорганизующийся рынок, «душа нации» и т. п. Последующая разработка этой проблемы в контексте социально-философского дискурса и за его пределами, «зондирование» хаотичной субстанции, противостоящей опредмечиванию и структурированию, на фоне ослабления позиций разума требовали, в свою очередь, переосмысления всей системы характеристик различных способов его проявления. Ключевое значение стали приобретать «негативные» категории разума: «отрицание», «ограничение», «критика», «ошибочность», в то время как традици- 
онные понятия: «порядок», «организация», «система», «структура», «эффективность», «предсказуемость», «планомерность», «контроль» отошли на второй план.

Категории, сохранившие свой потенциал после попыток демистификации и рационализации диалектики, как оказалось, вписывались в новую методологию, которая предлагала их «более гибкую интерпретацию» [20]. Их главная особенность заключалась в том, что в качестве основных атрибутов «нового» разума, они отражали не только его способность к развитию, но и склонность, с одной стороны, к самоограничению, к постоянной негативной рефлексии, а с другой,тенденцию к внутреннему отрицанию, к ошибочности, проникшей не только в рационализированное, но и в рационализирующее. В истоках фаллибилизма оставалась актуальной и традиционная функция разума - апелляция, пусть и косвенная, к «причинности», «порядку», «истине», однако в процессе его эволюции она приобрела несколько иной оттенок. По сути, вновь возникла проблема критики разума, на этот раз разума, утратившего априорность, «очищенного» от мистических противоречий, лишенного объективной идеи и познаваемого в своих конкретных проявлениях. «Маленький», «ограниченный» субъективный разум сделал «отрицание», «критику», «ошибочность» и «опровержение» частью собственной структуры, «вернув» их из диалектически понимаемого мира. Эта система в своих ранних проявлениях предлагала соответствующий ей практический идеал, характеризующийся атрибутивной верой в разум, скромностью, критичностью, умением учиться на собственных ошибках (Сократ-Кант-Поппер), противопоставляя его «всеохватывающему» рационализму (Платон-ГегельМаркс).

Особенностью такого понимания разума являлось и то, что конструируемые им посредством «критики», «ошибочности» и «опровержения» области рациональности выступали одновременно в двух формах: субъективной и объективной (интерсубъективной). Внутренние (субъективные) компоненты полагались первичными, «атомарными» относительно внешних, лишая их холистической субстанциальности.

В традиционном смысле (в классических либеральных концепциях) «атомарность» подразумевала буквально «сферу» свободы: развития способностей (Г. Спенсер [23]), стремления к возвышенным удовольствиям и избегания страданий (Д.С. Милль [15]) и т. п. в видимой связи с представлением о неделимом «атоме» (подобные аналогии допустимо отсылают к учению Эпикура). Этой сфере приписывалась «неделимость» в соответствии с порождающим ее исходным принци- 
пом, а область ее развития и силы сопоставлялась с прогрессом в его реализации. Поскольку «атомы» оставались «неделимыми» по отношению к социальному «телу», то возникал вопрос о границах их взаимодействия. Установить границы, так чтобы атомы сосуществовали, формируя целостность общества, оставаясь, максимально свободными - означало сформировать буквально идеальное общество «всеобщего счастья». В качестве границ, регулирующих взаимодействие атомов, и выступал разум как система соответствующих ограничений. Дискуссия состояла лишь в обсуждении способов ее формирования и воздействия - эволюционном пути саморазвития (нравственного чувства), то есть исходя из самих «атомов»-крайне «либерально», либо путем внутренней корректировки, исходящей из этой рациональной (властно-политической) прослойки, как пути к максимально доступному на данный момент «счастью».

Однако в новой дедуктивно-фаллибилистической версии рационализма атомы уже не являлись целостностями, они не имели надежного фундамента в виде, например, исходных нравственных чувств (были потенциально ошибочны) и поэтому требовали причастности к исходным формам интерсубъективного разума. Эта причастность состояла в том, что субъективное выступало как исторически рационализированное внешним, которое, в свою очередь, уже не виделось чем-то «сплошным», то есть, как отмечалось выше, обнаруживало в себе, не поддающиеся на данном этапе рациональной обработке «дефекты», вновь требовавшие постоянного, детализированного, более содержательного выявления и ограничения. Эти неопределенности, пустоты, таким образом, проходили постоянное «циклическое» ограничение, переходя и встраиваясь в субъективно-объективный и в рационализирующе-рационализируемый процесс. В его ходе разум пытался не столько избавиться от иррациональной субстанции, сколько ограничить ее, «ужиться» с ней, так как его эволюционная природа исключала (допускала в бесконечно отдаленной перспективе) целостную, сплошную, симметричную гармонию. Следовательно, рационализация в этом понимании не только приобретала характер бесконечного устранения «дефектов» путем упорядочивания продуктов материальной и духовной жизнедеятельности, но и предполагала процессы бесконечного воспроизводства и критического уточнения собственного содержания и структуры.

Природа разума, определяемая в этом контексте через интерсубъективность и понимаемая как сформировавшаяся посредством активности частных его проявлений, допускала, в свою очередь, возмож- 
ность возникновения ratio лишь при условии особого состояния этого внутреннего, исходного, субъективного. Субъективное понималось как изменчивое и относительно автономное. Оно обладало активностью и свободой. В этом смысле субъективные «атомы» уже были «равными». Однако, их равенство закреплялось и в том, что они воспроизводили плюралистический разум, который мог возникнуть лишь как ограничение, применяемое исходя из своей множественности, исключающее (в исторически различных масштабах) поглощение или растворение индивидуальных активностей в едином. Его свобода предполагала самоограничение равенством, а равенство - свободой, так как в каждом разумном индивиде он обнаруживал часть себя.

Воздействие (ограничение), которое не только осуществлял, но и испытывал интерпретируемый таким образом разум, порождало и феномен сопротивления, защиты от разрушающей критики. Благодаря внутренней неоднородности, он находил себя во множественных формах, испытывая их воздействие как внутреннее и как внешнее, и, следовательно, вынужден был постоянно уточнять собственные принципы («ядро»), пытаться сохранить их, сохраняя тем самым самого себя.

В заявленном значении критического разума обнаружилась и тенденция к его универсализации: поиску общего основания для науки, политики, морали (и как систем, и как деятельности, и как ее результата). Поскольку это основание обнаруживалось в критике, любой объект, понятие которого предполагало ее исключение, в этом отношении рассматривался как нечто иррациональное. Что же в таком случае представляли собой исторически сформированные ступени самоопределения разума, существующие вне синтеза критической рефлективности, предполагающей его внутреннюю плюралистическую автономность и способность к ограничению и самоограничению? (Такого рода пред-формы взятые сами по себе, по сути еще не могут быть названы разумом.)

Разум, отвергающий свободу другого как равного проявляется в нерефлексивной форме - он не обнаруживает, не видит себя во «множественном» единстве. Со стороны другого он - подчинение, власть, насилие, принуждение, другими словами, внешняя враждебная сила (на различных этапах своего становления этот прото-разум порождал соответствующие социальные структуры). Чем более он игнорирует критику (как равенство и свободу), создает упрощенный иллюзорный мир, тем более теряет универсальную целостность, замыкаясь в своей части. Формы некритического, нерефлексивного разума (пред-разума) с этой точки зрения - монологический стиль мышления, религиозный 
и политический догматизм.

Такой разум может проявляться как «видимость» критики, особенно в современной ситуации, когда ему приходится противостоять разуму подлинно критическому. Симптомы подобного состояния - тематика абсурда и связанные с ней мировоззренческие установки, социальная и ментальная инертность, апатия. Критика в этих условиях теряет эффективность, но существует как оболочка, игра, плохо маскирующая иррациональность.

«Негативные» феномены, проявляющиеся в различных поведенческих, практических, научно-исследовательских и иных установках представлялись с позиции критического разума как своего рода отклонения (подлежащие постепенному устранению) или, в лучшем случае, требующие ограничения и отживающие себя «в чистом виде» архаические состояния. В то же время принципы самого критического разума, признавались хоть и историчными, но исторически не необходимыми. Действительно, для истории их единство и полнота, являются скорее исключением из правила, чем самим правилом, не только в практической плоскости их реализации, но и как системы идей. Проявления этих принципов носят опосредованный социальной эволюцией характер, подразумевающий такие внешние факторы, как определенный тип экономических отношений, специфические формы политического устройства и даже географического расположения, а также систему (религиозных) ценностей, допускающих осознание и распространение идей равенства и свободы. В этом контексте возникает вопрос о статусе новой рациональности, ее отношении к действительности.

Современные критические рационалисты [4] настаивают на том, что ключевые идеи, заложенные в основе критицизма, являются ядром системы «демократия-наука». Синтез науки и демократии породил, по их мнению, «открытое общество» - в оптимистичном представлении сформировавшуюся к середине XX века западную цивилизацию. В более умеренном варианте, «открытое общество» рассматривается скорее не как сама цивилизация, а как ее специфический аспект, не обязательно доминирующий в конкретных условиях. Таким образом, вопрос «веры» в разум и в его прогресс-это вопрос «веры» в возможность рассматривать определенный (в идеале - максимально широкий) круг проблем в духе критицизма.

На фоне трансформаций современного общества и возникают опасения в твердости этой «веры», основанные на том, что научно-технический прогресс породил не столько реализацию принципов субъективного, человеческого разума, сколько ставшую возможной ее ин- 
формационно-идеологическую «симуляцию» [29]. Смысл такой «симуляции» состоит в том, что идея критики может подменяться ее видимостью - плоской, двухмерной моделью, лишенной внутреннего содержания, а «информационное общество» понимается как общество «виртуальной» свободы и «виртуального» равенства, существующее лишь постольку, поскольку идеологическая машина с развитием информационных технологий научилась манипулировать сознанием людей, их потребностями и интересами [25].

То есть «новая рациональность» может существовать как особая форма адаптации механизма, который даже если и прогрессирует путем проб и ошибок (капитал, рациональность - Маркс, Вебер), то продолжает существовать в духе некритической рациональности как враждебный человеческой сущности конструкт. Частная же, субъективная рациональность оказывается к нему мало причастна. Она реализуется как бы «сама по себе», по своим особым принципам: люди традиционно руководствуются житейским «здравым смыслом» часто не совместимым с критической рациональностью, пользуясь достижениями науки (как правило, являющимися побочным эффектом развития военных технологий), как какой-то данностью, с которой следует считаться. Складывается впечатление, что переход от «субъекта» к «социальным институтам», от «человека» к «людям» в этих условиях не может быть полностью реализован.

Здесь вырисовывается еще одна проблема. Это проблема потенциальной области распространения критического разума (если признавать его актуальность) или реальности рационального единства человечества. Выглядит так, как будто значительные массы людей «поражены» неразумностью в той мере, в какой они осознанно или нет, отвергают критический метод. Идея сделать их носителями критицизма, очевидно, и подразумевает проект «Просвещение», однако следует допустить или признать, что достижение такого состояния в значительных масштабах не представляется возможным. Требующие просветительской рационализации, социальные, ментальные или культурные слои оказались консервативными в вопросах критики, буквально «неуязвимыми» для нее, поскольку «моральный» выбор (между разумом и безумием), который им предстояло сделать, обусловлен традиционными (постоянно воспроизводящимися) способами их бытия. «Рационалист» в таком случае либо вынужден становиться «пророком», стремящимся обратить их в свою «веру», либо (сохраняя оптимизм), смириться с текущим (плохим, но, по его мнению, лучшим из возможных и улучшаемым) положением дел. По крайней мере, пред- 
полагается, что он должен иметь отношение к власти и ее институтам, что в силу психологических, экономических и иных факторов выглядит весьма проблематичным. Из этого можно заключить, что уровень «видимой» критики существует лишь для того меньшинства, которое этот уровень воспринимает. То есть универсализация критического разума - идеализация, преуменьшающая влияние практиковмакиавеллистов как на принятие решений «внутри» системы, так и на формирование и функционирование самой системы (см.: [1]).

Если же сохранять уверенность в том, что «старая» рациональность действительно в той или иной степени может быть преодолена, то закономерным выглядит требование максимизировать критику и, тем более, плюрализм. В этом смысле формируется обратный полуутопический образ общества всеобей критики и свободы, в котором вряд ли сможет существовать какая-либо система. Процедуры критики, то, как они должны работать, что именно считать опровержением, само понятие факта, в том числе социального факта, остаются проблематичными, в контексте того, что политическая и какая-либо иная социальная система по своей природе обладает инертностью, несовместимой с субъективной свободой.

Конечно, поиски универсальности для «новой рациональности» продолжились и вне пределов аналитической традиции, в числе альтернатив которой можно выделить разработку концепции «коммуникативного сообщества» и «коммуникативной рациональности» в рамках «трансцендентальной прагматики». По мнению К.-О. Апеля:

Когда речь идет о предельном основании посредством трансцендентальной рефлексии, философствующему не надо выбирать, будет ли он принадлежать к критическому коммуникативному сообществу догматически или же в силу «иррационального решения» (К. Поппер), ибо в качестве аргументирующего он всегда уже имплицитно признает предпосылку неограниченного критического коммуникативного сообщества [5, с. 195].

Подобное обоснование рациональности могло быть, с точки зрения Апеля, достигнуто и в критическом рационализме, при условии принятия последним «диалектического понимания опыта» [там же, с. 198], «диалектической проблематики истории в духе Гегеля» [там же, с. 199], и «отречения от глубинных предпосылок современного сциентизма» [там же, с. 200], что позволило бы выявить путем философской рефлексии фиксацию рациональной общности индивидов как их способности к коммуникации. 
Однако действительность общества коммуникации противоречит его долженствованию как реальное - идеальному, а коммуникативная предпосылка может реализовываться в том числе и как монолог (который можно интерпретировать как симптом того, что мы называли пред-рациональностью). Отсюда можно заключить, что для качественного проявления разума с необходимостью должны проявляться принципы свободы и равенства, о которых говорилось выше.

Если, исходя из вышеизложенного, говорить об основных тенденциях в осмыслении феноменов знания и рациональности, то можно прийти к тому заключению, что в условиях активной реализации альтернативных (противоречащих) ему форм, субъективный критический разум обнаруживает, по крайне мере, тенденцию к становлению и самоидентификации. Даже если он существует в виде того, что только «должно быть» (а он претендует на гораздо большее), и в этом проявлении разум оказывает воздействие на реальность. Его современная версия предполагает последовательную реконструкцию посредством «субстанциализации» субъективной свободы: либо она реализуется как контролируемый, ограничиваемый хаос, либо осуществляется как хаос неотличимый от порядка. В таком понимании разума отображается, на наш взгляд, ключевая особенность его исторического типа - признание иррациональной сущности, коренящейся, в том числе, и в его собственной природе.

\section{Литература}

[1] Абдула А.И. Демократия и легитимность // Актуальні проблеми духовності. - Кривий Ріг, 2012. - Вип. 13. - С. 193-200.

[2] Августин А. Исповедь.- М. : Ренессанс, 1991.

[3] Августин Блаженный. О Граде Божием : в 4 т. - Т. 3 : Книги IXIII. - СПб. : Алетейя, 1998.

[4] Алъберт X. Трактат о критическом разуме.-М.: Едиториал yPCC, 2003.

[5] Anель K.-О. Трансформация философии. - М. : Логос, 2001.

[6] Вебер М. Избранные произведения. - М. : Прогресс, 1990.

[7] Витгенштейн Л. О достоверности // Витгенштейн Л. Философские работы. Часть І. - М. : Гнозио, 1994. - С. 321-405. 
[8] Гегель Г.В.Ф. Энциклопедия философских наук : в 3 т. - Т. 1 : Наука логики. - М. : Мысль, 1970.

[9] Гуссерль Э. Кризис европейских наук и трансцендентальная феноменология. - СПб. : Владимир Даль, 2004.

[10] Декарт Р. Сочинения. - СПб. : Наука, 2006.

[11] Дюркгейм Э. Социология. Ее предмет, метод, предназначение. М. : Канон, 1995.

[12] Кант И. Критика чистого разума. - М. : Мысль, 1994.

[13] Лебон Г. Психология толп // Г. Лебон Психология толп. - М. : Институт психологии РАН, КСП+, 1998. - С. 15-256.

[14] Маркс К. Немецкая идеология // Маркс К., Энгельс Ф. Сочинения : в 50 т. - М. : Госполитиздат, 1955. - Т. 3. - С. 5-544.

[15] Милль Д.С. Утилитаризм. - Ростов-на-Дону : Донской издательский дом, 2013.

[16] Ницше Ф. Генеалогия морали // Ф. Ницше Собрание сочинений: в 5 т. - СПб. : Азбука, Азбука-Аттикус, 2011. - Т. 5. - С. 19-87.

[17] Пирс Ч. Начала прагматизма. - СПб. : Лаборатория метафизических исследований философского факультета СПбГУ; Алетейя, 2000 .

[18] Платон. Законы // Платон. Собрание сочинений: в 4 т. - М.: Мысль, 1994. - Т. 4. - С.71-438.

[19] Платон. Парменид // Платон. Собрание сочинений: в 4 т. - М. : Мысль, 1993. - Т. 2. - С. 316-413.

[20] Поппер K. Что такое диалектика? // Вопросы философии. 1995. - № 1. - С. 188-139.

[21] Порус B.Н. Рациональность. Наука. Культура. - М. : Университет российской академии образования, 2002.

[22] Сартр Ж.-П. Бытие и ничто: Опыт феноменологической онтологии. - М. : Республика, 2000. 
[23] Спенсер Г. Политические сочинения : в 5 т. - М.: Социум, 20142015.

[24] Фрейд 3. Неудовлетворенность культурой // Фрейд 3. Сочинения: в 10 т. - М. : Фирма СТД, 2007. - Т. 9. - С. 191-271.

[25] Фромм Э. Забытый язык. Иметь или быть? - М. : АСТ, 2009.

[26] Фуко М. История безумия в классическую эпоху. - М.: ЛСТ MOCKBA, 2010.

[27] Шопенгауэр А. Мир как воля и представление // Шопенгауэр А. Сочинения: в 10 т. - М. : ТЕРРА-Книжный клуб; Республика, 1999. - T. 1. - C. 4-452.

[28] Эволюиионная эпистемология и логика социальных наук: Карл Поппер и его критики. - М. : Эдиториал УРСС, 2000.

[29] Ясперс K., Бодрийар Ж. Призрак толпы. - М. : Алгоритм, 2007.

Надійшла до редакиї̈ 1 липня 2016 р. 


\section{Анотація}

Абдула А.І. Розум, раціональність, суб’єкт

Розглядається коло питань, пов'язаних 3 проблематикою розуму та раціональності. Пропонується суб'єктна інтерпретація взаємозв'язку, розвитку та протиставлення різних форм розуму. Висвітлюються варіативні та субстанційні аспекти внутрішньої структури раціонального, рівні його співвідношення 3 ірраціональним. Аналізуються соціальні аспекти функціонування раціональності.

Ключові слова: розум, раціональність, помилковість, критика, ірраціональне, структура, суб’єкт.

\section{Abstract}

Abdula A.I. Reason, rationality, subject

The paper is devoted to some problems connected with an issue of reason and rationality. The author proposes a subjective interpretaion of an interrelation between various forms of reason and their development. The variative and substantive aspects of the internal structure of rationality are explained, as well as the levels of its intersonnestion with irrationality. The paper presents also an analysis of some social dimensions of rationality.

Keywords: Reason; rationality; falsehood; criticism; irrational; structure; subject

\section{References}

1. Abdula A.I. Demokratiya i legitimnost // Aktualni problemy duhovnosti. Krivij Rig, 2012. — Vip. 13. — S. 193-200.

2. Augustin A. Ispoved. — M. : Renessans, 1991.

3. Augustin Blazhennyj. O Grade Bozhiem : v 4 t. — T. 3 : Knigi I-III. — SPb. : Aletejya, 1998.

4. Albert H. Traktat o kriticheskom razume. - Moscow : Editorial URSS, 2003.

5. Apel K.-O. Transformaciya filosofii. — Moscow : Logos, 2001. 
6. Weber M. Izbrannye proizvedeniya. — Moscow : Progress, 1990.

7. Wittgenstein L. O dostovernosti // Witgenstein L. Filosofskie raboty. Chast I. — Moscow : Gnozio, 1994. — S. 321-405.

8. Hegel G.W.F. Enciklopediya filosofskih nauk : v 3 t. — T. 1 : Nauka logiki. — Moscow : Mysl, 1970.

9. Husserl E. Krizis evropejskih nauk i transcendentalnaya fe- nomenologiya. — SPb. : Vladimir Dal, 2004.

10. Descartes R. Sochineniya. — SPb. : Nauka, 2006.

11. Durkheim E. Sociologiya. Ee predmet, metod, prednaznachenie. Moscow : Kanon, 1995.

12. Kant I. Kritika chistogo razuma. - M. : Mysl, 1994.

13. Lebon G. Psihologiya tolp // G. Lebon Psihologiya tolp. - M. : Institut psihologii RAN, KSP+, 1998. - S. 15-256.

14. Marx K. Nemeckaya ideologiya // Marx K., Engels F. Sochineniya : v 50 t. — Moscow : Gospolitizdat, 1955. - T. 3. - S. 5-544.

15. Mill D.S. Utilitarizm. — Rostov-na-Donu : Donskoj izdatelskij dom, 2013.

16. Nietzsche F.W. Genealogiya morali // F. Nicshe Sobranie sochinenij: v 5 t. SPb. : Azbuka, Azbuka-Attikus, 2011. — T. 5. — S. 19-87.

17. Peirce C.S. Nachala pragmatizma. - SPb. : Laboratoriya metafizicheskih issledovanij filosofskogo fakulteta SPbGU; Aletejya, 2000.

18. Plato. Zakony // Platon. Sobranie sochinenij: v 4 t. — M. : Mysl, 1994. — T. 4. - S. 71-438.

19. Plato. Parmenid // Platon. Sobranie sochinenij: v 4 t. — M. : Mysl, 1993. — T. 2. - S. 316-413.

20. Popper K. Chto takoe dialektika? // Voprosy filosofii. — 1995. — № 1. - C. 188-139.

21. Porus V.N. Racionalnost. Nauka. Kultura. — Moscow : Universitet rossijskoj akademii obrazovaniya, 2002.

22. Sartr J.-P. Bytie i nichto: Opyt fenomenologicheskoj ontologii. - Moscow : Respublika, 2000. 
23. Spencer H. Politicheskie sochineniya : v 5 t. — Moscow : Socium, 20142015.

24. Freud S. Neudovletvorennost kulturoj // Frejd Z. Sochineniya: v 10 t. Moscow : Firma STD, 2007. — T. 9. — S. 191-271.

25. Fromm E. Zabytyj yazyk. Imet ili byt? — Moscow : ACT, 2009.

26. Foucault M. Istoriya bezumiya v klassicheskuyu ehpohu. — Moscow : LST MOSKVA, 2010.

27. Schopenhauer A. Mir kak volya i predstavlenie // Schopenhauer A. Sochineniya: v 10 t. — Moscow : TEPPA-Knizhnyj klub; Respublika, 1999. - T. 1. - S. 4-452.

28. Evolyucionnaya ehpistemologiya i logika social'nyh nauk: Karl Popper i ego kritiki. — Moscow : Editorial URSS, 2000.

29. Jaspers K., Baudrillard. Prizrak tolpy. — Moscow : Algoritm, 2007. 